\title{
Characterization of glutathione S-transferases from the pine wood nematode, Bursaphelenchus xylophilus
}

\author{
Margarida EsPAdA ${ }^{1,2}$, John T. Jones ${ }^{2,3}$ and Manuel MotA ${ }^{1,4, *}$ \\ ${ }^{1}$ NemaLab/ICAAM - Instituto de Ciências Agrárias e Ambientais Mediterrânicas, Universidade de Évora, \\ Núcleo da Mitra, Ap. 94, 7002-554 Évora, Portugal \\ ${ }^{2}$ Cell and Molecular Sciences Group, The James Hutton Institute, Invergowrie, Dundee DD2 5DA, UK \\ ${ }^{3}$ School of Biology, University of St Andrews, North Haugh, St Andrews KY16 9TZ, UK \\ ${ }^{4}$ Departamento de Ciências da Vida, Universidade Lusófona de Humanidades e Tecnologias, EPCV, C. Grande 376, \\ 1749-024 Lisbon, Portugal
}

Received: 29 January 2016; revised: 5 April 2016 Accepted for publication: 7 April 2016; available online: 10 May 2016

\begin{abstract}
Summary - We have previously identified two secreted glutathione S-transferases (GST) expressed in the pharyngeal gland cell of Bursaphelenchus xylophilus, which are upregulated post infection of the host. This study examines the functional role of GSTs in $B$. xylophilus biology. We analysed the expression profiles of all predicted GSTs in the genome and the results showed that they belong to kappa and cytosolic subfamilies and the majority are upregulated post infection of the host. A small percentage is potentially secreted and none is downregulated post infection of the host. One secreted protein was confirmed as a functional GST and is within a cluster that showed the highest expression fold change in infection. This enzyme has a protective activity that may involve host defences, namely in the presence of terpenoid compounds and peroxide products. These results suggest that GSTs secreted into the host participate in the detoxification of host-derived defence compounds and enable successful parasitism.
\end{abstract}

Keywords - detoxification metabolism, effectors, plant-parasitic nematode, terpenoid compounds.

Glutathione S-transferases (GST, EC 2.5.1.18) are enzymes involved in detoxification metabolism and are present in a range of different organisms including bacteria, plants and animals. The main function of this large family of enzymes is the detoxification of potentially damaging endogenous stress products and exogenous xenobiotic compounds, and also an important role in drug metabolism. This is achieved by the ability to catalyse the conjugation of the reduced form of glutathione (GSH) to potential toxins in order to increase their solubility and thus enable them to be metabolised or excreted from the host (Brophy \& Pritchard, 1994; Campbell et al., 2001; Torres-Rivera \& Landa, 2008; Matoušková et al., 2016). GST does not act directly on reactive oxygen species (ROS), but on the oxidised products of their activity, including lipid hydroperoxides and reactive carbonyls (Torres-Rivera \& Landa, 2008). In parasitic species GST is an important detoxification enzyme, especially in helminths where GSTs provide initial defence against oxidative damage and protect the worm from the host immune response, as well as acting as drug-binding proteins (Precious \& Barrett, 1989; Brophy \& Barrett, 1990; Brophy \& Pritchard, 1994; Matoušková et al., 2016). Therefore, the roles of these enzymes in the hostparasite interaction have been studied extensively. Recent studies on GSTs from animal-parasitic helminths showed that sigma-GSTs have prostaglandin synthase activity, and bind to toxins as a suppression of the host immune response to the benefit of the parasite (van Rossum et al., 2004; Dowling et al., 2010; LaCourse et al., 2012). In addition, analysis of the secretome of the animal-parasitic trematode Fasciola hepatica, revealed sigma class-GST in extracellular vesicules that are deployed during parasitism (Cwiklinski et al., 2015). In the plant-parasitic nematode Meloidogyne incognita, one GST has been identified as being secreted from the pharyngeal gland cells (Mi-gst-1) and plays an important role in the interaction with the host as evidenced by the fact that silencing of this gene by RNAi leads to a reduction in parasitism. This GST may protect the nematode against host-derived ROS or may

* Corresponding author, e-mail: mmota@uevora.pt 
modulate plant responses that are triggered by nematode attack (Dubreuil et al., 2007).

Parasitic helminths contain several forms of GSTs that can be grouped in subfamilies on the basis of their subcellular location: kappa (mitochondrial), microsomal and cytosolic (soluble GSTs from the mu, alpha, pi, theta, sigma, zeta and omega classes) (Frova, 2006; Torres-Rivera \& Landa, 2008). Several GSTs have been identified in migratory plant-parasitic nematodes, including Bursaphelenchus xylophilus, Ditylenchus africanus, Pratylenchus coffeae, Radopholus similis and from the sedentary species Meloidogyne spp. and Globodera pallida (Dubreuil et al., 2007; Bellafiore et al., 2008; Jacob et al., 2008; Haegeman et al., 2009, 2011; Kikuchi et al., 2011; Cotton et al., 2014; Espada et al., 2016). A total of 65 potential GSTs were predicted from the genome of B. xylophilus, a similar number to that in Caenorhabditis elegans, but higher than seen in other plant-parasitic nematodes (Kikuchi et al., 2011).

When the pine wood nematode (PWN) B. xylophilus infects a tree it triggers several physical and chemical alterations leading to the symptoms of pine wilt disease (PWD). Kuroda et al. (1991) hypothesised a mechanism of cavitation, in which terpenoids synthesised in xylem ray cells induce cavitation and embolisms in tracheids leading to failure of water transport. Previous studies have shown that levels of plant terpenes in Pinus thunbergii, particularly $\alpha$-pinene and $\beta$-pinene, increase when the tree is infected by B. xylophilus (Kuroda, 1991; Kuroda et al., 1991; Fukuda et al., 1997). However, a recent study examining infection of plant material maintained in tissue culture suggested that terpenoid compounds do not significantly increase after infection with PWN although levels were maintained after infection, with $\alpha$-pinene making up between 26-32\% of total terpenoid content and $\beta$-pinene between 34-47\% (Faria et al., 2015). Several of these compounds have nematicidal activity, although no study has been made in B. xylophilus. Chemical compounds including terpenoids have been tested against filarial nematode GST and one study showed that $\alpha$ pinene has an inhibitory effect on the nematode GST (Azeez et al., 2012).

In a previous study, we identified two secreted glutathione S-transferases that were upregulated in an early stage of infection and which are expressed in the dorsal pharyngeal gland cell (Espada et al., 2016). It was suggested that these enzymes could be involved in detoxification of plant endogenous compounds, helping B. xylophilus to overcome host defences. Here we demonstrate that at least one of these is a functional GST and that the presence of this enzyme provides protection against stresses likely to be encountered during infection of the host tree. We show that biochemically active GST is secreted by nematodes. In addition, we examine the global changes in expression of B. xylophilus GSTs upon infection of the host.

\section{Materials and methods}

\section{Phylogenetic ANALysis of GST SEQUenCes}

Potential GST-encoding sequences were identified using the previous data from Kikuchi et al. (2011) and by BLASTP searching the gene calls from the $B . x y$ lophilus genome against the NR database (cutoff $1 \mathrm{e}^{-5}$ ). Any sequences for which at least one of the top three hits included the expression "glutathione S-transferase" were selected for further analysis. This analysis was performed using BLAST+ wrappers for Galaxy (v0.1.01) (Cock et al., 2015). The expression levels of the transcripts at various life stages were predicted from RNAseq data generated in a previous study (Espada et al., 2016) and $\log _{2}$ of the fold change for each gene was calculated. For all the predicted GSTs the subfamilies and protein domains were identified using InterProScan 5 (Jones et al., 2014) (http://www.ebi.ac.uk/interpro/search/ sequence-search). Secreted GSTs were predicted based on the presence of signal peptide as predicted by SignalP (v3.0) (Bendtsen et al., 2004) and the absence of a transmembrane domain. All the alignments of the full-length protein sequences were performed with the software SeaView (Gouy et al., 2010). The Maximum-likelihood phylogenetic tree was generated by PhyML (in SeaView) from the alignment of the sequences (protein distance measure: Jukes-cantor; aLRT SH-like for branch supporting). The phylogenetic tree was edited in FigTree (v1.4.0) (http://tree.bio.ed.ac.uk/software/figtree/). A neighbourjoining phylogenetic tree was generated in the software CLC Sequence Viewer (v7.6.1) (protein distance measure: Jukes-cantor; one thousand replicates for bootstrap for branch supporting).

\section{BIOLOGICAL MATERIAL}

Nematodes were cultured on Botrytis cinerea and harvested using a Baermann funnel as previously described (Espada et al., 2016). Secreted proteins were collected as described in Kikuchi et al. (2004). Briefly, mixed lifestage nematodes were collected in a $15-\mathrm{ml}$ tube, by centrifugation at $2844 \mathrm{~g}$ for $15 \mathrm{~min}$, suspended in $1 \mathrm{ml} \mathrm{M} 9$ 
buffer and incubated for 2 days at $18^{\circ} \mathrm{C}$. Thereafter the sample was centrifuged at $2844 \mathrm{~g}$ to pellet the nematodes, the supernatant containing secreted proteins was collected and stored in aliquots at $-80^{\circ} \mathrm{C}$ until used in enzyme assays.

\section{CLONING IN EXPRESSION VECTOR AND PROTEIN PURIFICATION}

The primers to amplify the full-length of one of the B. xylophilus GSTs shown to be expressed in the dorsal pharyngeal gland cells (BUX.s00647.112) were designed from the cDNA sequence lacking the signal peptide (as predicted by SignalP 3.0). The gene specific primers included the Kozak sequence (ACCATG) in the forward primer ( $5^{\prime}$ ACCATGTTAGAGCTGTATTATTTCAACGA GAAG) and a Stop codon (TGA) in the reverse primer (5'TGATTGAGTGGCATTGAAATAATTGTAAATCG). The full length gene was amplified using KOD Hot Start proof-reading DNA polymerase and purified using the QIAquick gel extraction Kit (Qiagen). The gene was cloned into the pCR8 TOPO vector and transformed in one shot TOP10 competent cells following the manufacturer's instructions (Invitrogen). The recombinant clones were screened by colony PCR and one clone was confirmed by sequencing. Purified entry plasmid (approximately $140 \mathrm{ng}$ ) was transferred to the destination vector pJC40 (a 10× His-tag N-terminus fusion vector) using the LR cloning kit following the manufacturer's instructions (Invitrogen). The cloning reaction was transformed into BL21(DE3) chemical competent cells. Positive transformants (construct pJC40 + 00647.112) were analysed by colony PCR and confirmed by sequencing. The His-tagged protein was induced by adding $1 \mathrm{mM}$ IPTG (isopropyl-beta-D-thiogalactopyranoside) to a bacterial culture grown from a single colony in $10 \mathrm{ml} \mathrm{LB}$ with $100 \mu \mathrm{g} \mathrm{ml}^{-1}$ ampicillin at $37^{\circ} \mathrm{C}$ until the concentration reached an $\mathrm{OD}_{600}$ of 0.6 . The protein was then purified using Ni-NTA resin columns (Ni-NTA Spin kit, Qiagen) following the manufacturer's protocol.

\section{RESISTANCE TEST IN BL21(DE3) CELLS}

To induce expression of the recombinant protein, a single colony was grown in $45 \mathrm{ml} \mathrm{LB}$ and $100 \mu \mathrm{g} \mathrm{ml}^{-1}$ of ampicillin at $37^{\circ} \mathrm{C}$ with agitation until the concentration reached an $\mathrm{OD}_{600}$ of 0.6 . At this point $100 \mu \mathrm{l}$ aliquots of the bacterial suspension were placed in new sterile $15 \mathrm{ml}$ tubes containing $4 \mathrm{ml} \mathrm{LB}$ and to which the terpenes (limonene, $(+)$ and $(-)$ - $\alpha$-pinene, $(-)$ - $\beta$-pinene) or hydrogen peroxide were added. For each treatment, two dif- ferent concentrations were tested and two replicates were used: $0.5 \%$ and $1 \%$ for limonene, $(+)$ and $(-)-\alpha$-pinene, (-)- $\beta$-pinene (Sigma-Aldrich); $1 \%$ and $3 \%$ for hydrogen peroxide. Protein expression was induced in the remaining bacterial suspension by adding $0.5 \mathrm{mM}$ IPTG and incubating at $37^{\circ} \mathrm{C}$, with agitation, for $2 \mathrm{~h}$. After this time the terpenoid and hydrogen peroxide treatments were repeated using $100 \mu \mathrm{l}$ aliquots of the bacterial suspension as described above. The respective control tubes were also grown in the same conditions. All the treatments were subsequently grown overnight at $37^{\circ} \mathrm{C}$ with agitation. The $\mathrm{OD}_{600}$ was measured for all treatments in a spectrophotometer (Spekol 1500, Analytik Jena). The results were analysed with an ANOVA test using the statistical software GenStat (version 17; VSN International, 2012).

\section{WESTERN BLOTTING}

Aliquots of the bacterial cells from test described above were used in a Western blot using an antibody against a poly-histidine tag (Sigma-Aldrich) to demonstrate the presence of the recombinant protein in the assay. The bacterial extracts were heated at $90^{\circ} \mathrm{C}$ for $10 \mathrm{~min}$ in NuPage LDS sample buffer (Invitrogen). The proteins were separated on a 4-12\% NuPage Bis-Tris gel (Invitrogen) and transferred to nitrocellulose membrane (GE Healthcare). Immuno-detection of the protein was performed using anti-His antibody (Sigma) at 1:5000 dilution as primary antibody and detected using a secondary antibody conjugated to peroxidase ( $\alpha$-mouse IgGxHRP at 1:50 000) (Sigma) by chemiluminescence using the Pierce Supersignal West Pico kit (Thermo-Scientific).

\section{ENZYME ASSAY}

The glutathione-S-transferase assay kit (SigmaAldrich) was used with 1-chloro-2,4-dinitrobenzene (CDNB) as the standard substrate to test activity of recombinant protein and activity present in collected secretions. All assays were replicated three times. A solution containing $2 \mathrm{mM}$ reduced L-glutathione and $1 \mathrm{mM} \mathrm{CNDB}$ in Dulbecco's phosphate buffered saline was prepared and used within an hour of preparation; $50 \mu 1$ aliquots of this solution were mixed with $1 \mu \mathrm{l}$ of control GST enzyme or with test enzyme preparations and transferred to a quartz cuvette. Absorbance was measured at $340 \mathrm{~nm}$, for $30 \mathrm{~s}$ each over a period of $5 \mathrm{~min}$, after a lag time of $1 \mathrm{~min}$, following the manufacturer's procedure. GST activity was calculated for each sample as described by the kit manufacturer. 


\section{Results and discussion}

\section{GLOBAL ANALYSIS OF B. XYLOPHILUS GST EXPRESSION PROFILES}

An analysis of GSTs performed as part of the $B$. $x y$ lophilus genome project (Kikuchi et al., 2011) identified 65 potential GSTs. Our BLASTP based analysis of the B. xylophilus genome revealed that five more sequences, which could encode proteins similar to GSTs, were present (Fig. 1). Analysis of the protein domains present in each sequence confirmed all the protein se- quences as GSTs, as shown in the supplementary table (Table S1 in the Supplementary material). The majority of these sequences have a thioredoxin-like fold domain (IPR012336) followed by glutathione S-transferase Nterminal and C-terminal domains, both of which are features of a cytosolic subfamily (reviewed in Frova, 2006). Five sequences contained domains similar to maleylacetoacetate isomerase (IPR005955), which is a feature of the zeta class of GSTs. The other four sequences were identified as kappa subfamily GSTs, due to the presence of the DSBA-like thioredoxin domain (IPR01853) (a feature

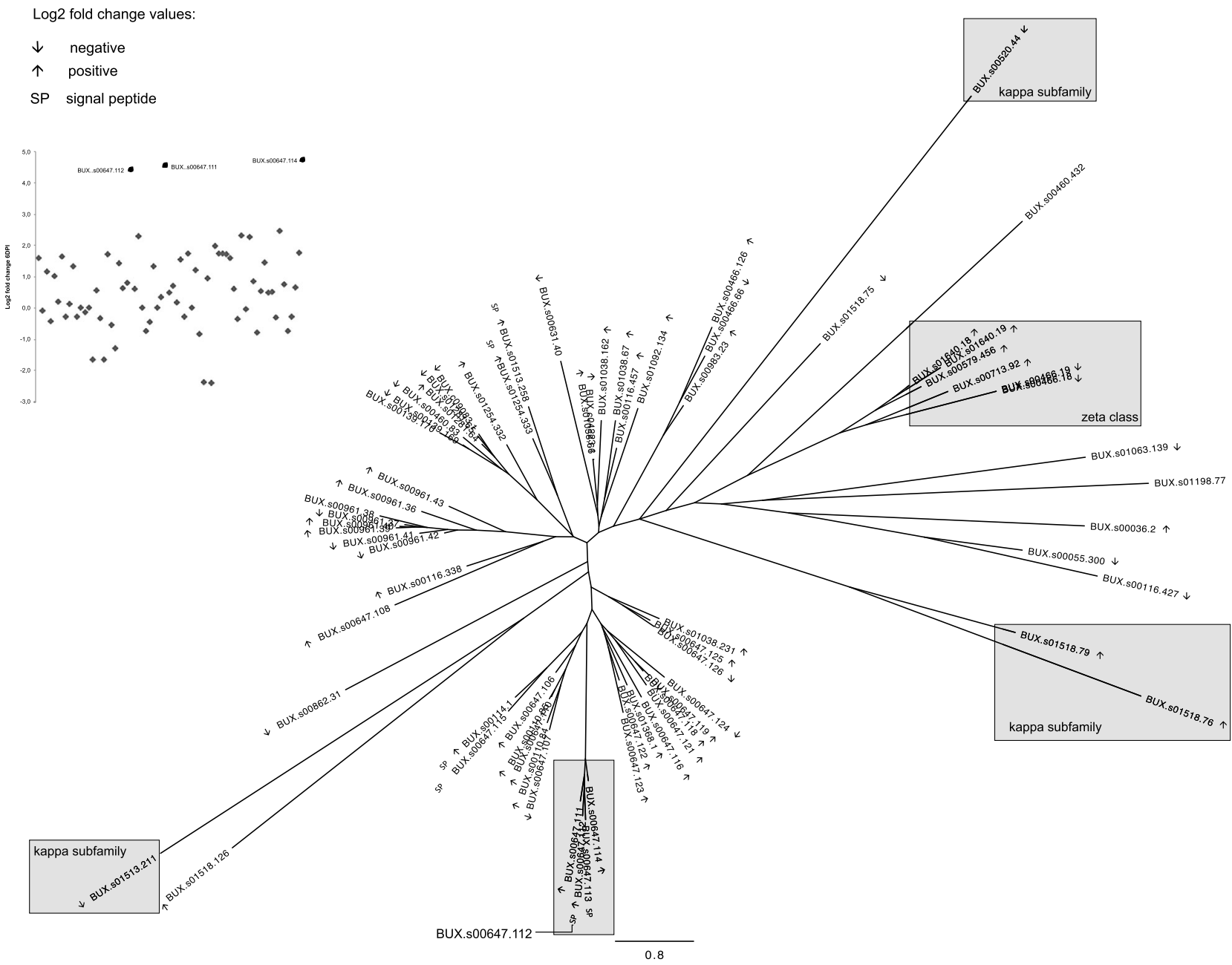

Fig. 1. Maximum-likelihood phylogenetic tree that represents the protein sequence similarity between all 70 Bursaphelenchus xylophilus predicted GSTs. The GSTs belonging to the kappa subfamily and to the cytosolic zeta class are represented within grey boxes. For each gene the $\log _{2}$ of the fold changes ( 6 days post infection) values of the expression levels are represented by arrows. The highest $\log _{2}$ fold change values belong to the genes BUX.s00647.112, BUX.s00647.111 and BUX.s00647.114 that cluster together (grey box). The dot plot on the top left of the figure is a representative chart of the expression values of all genes. SP represents the presence of a signal peptide. 
of the HCCA isomerase/GST kappa family - IPR01440) (Frova, 2006).

Six of the GST sequences have a predicted signal peptide, suggesting a role in detoxification of extracellular compounds, including host-derived toxins (Fig. 1). These potentially secreted proteins included the two sequences (BUX.s00647.112 and BUX.s01254.333) that were previously identified as being expressed in the pharyngeal gland cells (Espada et al., 2016). Next we used our previously described RNAseq dataset to examine global changes in expression profiles of the GST sequences, by using $\log _{2}$ of the fold changes. This showed that 42 of the GST sequences are upregulated in nematodes after infection of trees as compared to nematodes grown on fungi (Fig. 1), including four of those sequences with a signal peptide. None of the secreted GSTs was downregulated after infection. The maximum-likelihood phylogenetic analysis (Fig. 1) of the B. xylophilus GSTs and sequences from other nematodes showed that the pharyngeal gland cell sequences clustered with other sequences upregulated after infection. One (BUX.s01254.333) formed a cluster with other secreted and upregulated protein while the other (BUX.s00467.112) clustered with another secreted protein and two other upregulated proteins. This cluster includes the sequences that show the highest increases in expression during the infection of the host. Neither the pharyngeal gland cell GSTs, nor the secreted GSTs formed a single cluster (although the secreted GSTs were present as pairs in three clusters). These clusters were consistent in a neighbour-joining phylogenetic analysis (see Fig. S1 in the Supplementary material). These data suggest that a range of the GSTs present in B. xylophilus have been recruited independently to play a role in protection against host derived toxins and that the range of secreted GSTs has not evolved as a result of duplication of a single secreted ancestor.

\section{ENZYMATIC AND PROTECTIVE ACTIVITY OF GSTS INVOLVED IN THE HOST-PARASITE INTERACTION}

We next examined the biochemical activity of one of the pharyngeal gland cell GST sequences. The recombinant BUX.s00647.112 protein was cloned into an expression vector with an N-terminal His tag and purified from bacterial cell lysate, yielding a protein of approximately $25 \mathrm{KDa}$, in agreement with the size predicted from the amino acid sequence (Fig. 2). The recombinant protein had glutathione transferase activity (using CDNB as a substrate) very similar to that observed for the positive control (Table 1). These data confirm that the BUX.s00647.112 protein is a functional GST.

Our previous data showed that several GSTs (including the BUX.s00647.112 sequence) are expressed in the pharyngeal gland cells, from where they could be secreted
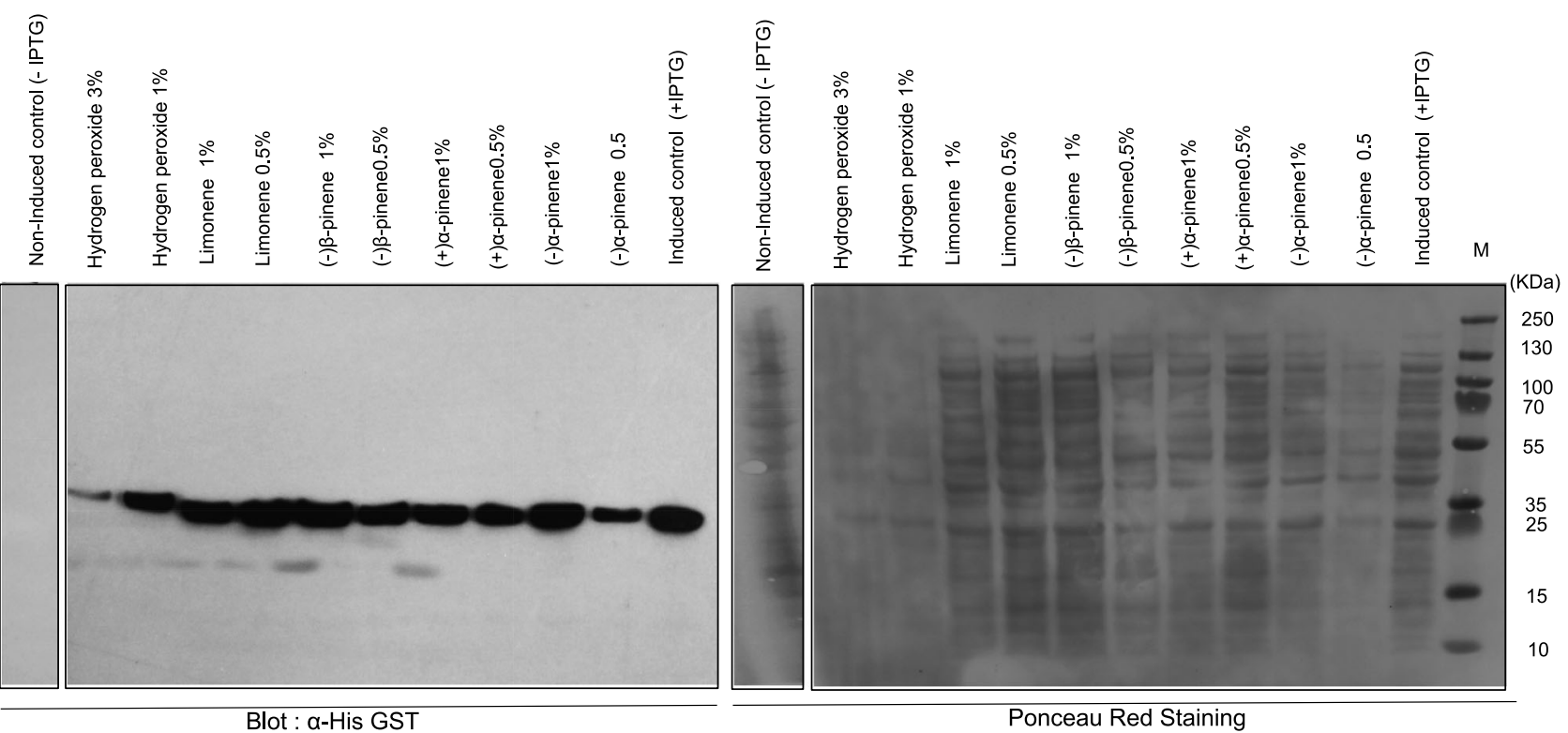

Fig. 2. The results of the immuno-detection of anti-Histag on the recombinant BUX.s00647.112 protein resistance assays. On the right, the Ponceau Red staining and on the left the results of the blot detected by chemiluminescence. M: protein ladder (GeneRuler, Thermofisher). 
into the host. In addition, a larger scale proteomic analysis of B. xylophilus secreted proteins identified several peptides that could be derived from GST sequences (Shinya et al., 2013) further suggesting that GSTs form an important component of the B. xylophilus repertoire of secreted proteins. In keeping with this, we were able to detect GST

Table 1. Glutathione transferase activity results using CDNB as substrate (blank) in recombinant BUX.s00647.112 protein, Bursaphelenchus xylophilus protein extract and secretions. Each value is in the form mean \pm SD.

\begin{tabular}{lc}
\hline $\begin{array}{l}\text { Sample } \\
\text { (CDNB as substrate) }\end{array}$ & $\begin{array}{c}\text { GST activity } \\
\left(\mu \mathrm{mol} \mathrm{ml}^{-1} \mathrm{~min}^{-1}\right)\end{array}$ \\
\hline GST activity in crude extracts of PWN proteins and secretions \\
GST (control) & $133.7 \pm 62.3$ \\
PWN secretions & $31.2 \pm 1.9$ \\
PWN proteins & $37.1 \pm 0.2$ \\
GST activity in the recombinant BUX.s00647.112 protein \\
GST (control) & $1509.8 \pm 73.4$ \\
Recombinant BUX.s00647.112 & $2096.3 \pm 312.5$ \\
\hline
\end{tabular}

The GST protein control was provided in the kit (Sigma). activity (albeit at low levels) in secretions collected from B. xylophilus (Table 1). The RNAseq data suggest that it would have been possible to detect higher GST activity in secretions harvested from nematodes extracted from trees but technical limitations prevented us from attempting this analysis.

We next sought to analyse whether the B. xylophilus pharyngeal gland cell GST can provide protection against the toxins likely to be encountered by a nematode infecting a pine tree. Testing the function of the GST in pine trees is not possible due to technical limitations. We therefore compared the ability of bacterial cells in which the GST was either induced or not induced to grow in the presence of hydrogen peroxide and several terpenoid compounds. The peroxide was intended to represent the products of ROS, whilst the terpenoids were chosen to mimic toxic compounds likely to be present in an infected pine tree. In the presence of the GST, bacteria showed significantly higher growth in an environment with a $(-)$ and $(+)-\alpha$-pinene (-)- $\beta$-pinene, $0.5 \%$ limonene and up to $3 \%$ hydrogen peroxide (Fig. 3). There were no significant

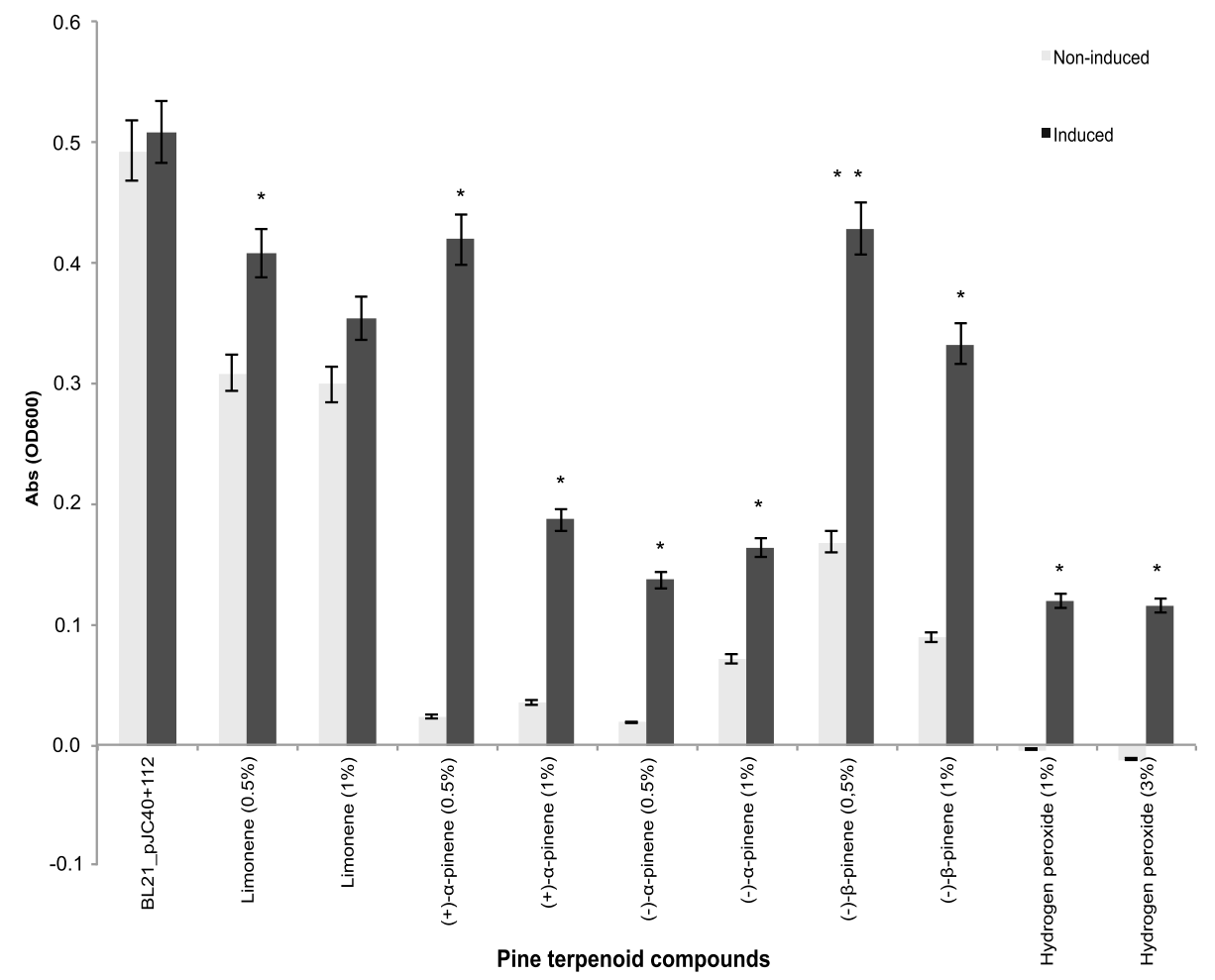

Fig. 3. Resistance test in BL21(DE3) cells. Induced $v s$ non-induced BUX.s00647.112 protein using different pine terpenoid compounds and different concentrations of each ( $x$-axis). The values on the $y$-axis correspond to values of absorbance $\left(\mathrm{OD}_{600}\right)$. The LB media was used to grow the bacteria. Protein expression was induced with $0.5 \mathrm{mM}$ IPTG (see Materials and methods). Significant differences between induced and non-induced treatments were analysed by ANOVA $\left({ }^{*} P<0.05\right.$; ${ }^{* *} P<0.01$ ). 
differences in the $1 \%$ limonene treatment or in the control (induced $v s$ non-induced). The difference in growth rate was most apparent in the presence of $0.5 \%(-)-\beta$ pinene. A Western blot (Fig. 2) showed that the recombinant GST was present in all IPTG-induced samples while the non-induced bacterial cells showed no signal in the blot (Fig. 2).

These data confirm that B. xylophilus secretes functional GST proteins into the host, which may be important for allowing the nematode to overcome host defences. This may be a strategy that is widely used by plant-parasitic nematodes: a secreted GST has been identified from $M$. incognita (Mi-gst-1) that has been shown to promote infection of this nematode (Dubreuil et al., 2007) and which is also thought to function by protecting the nematode from host defences. Like the B. xylophilus sequence, the $M$. incognita GST is upregulated upon infection and expressed in the pharyngeal gland cells. GSTs also form a significant component of the strategy used by animal-parasitic nematodes to neutralise host defence responses. It is likely that GSTs used for internal metabolic processes have become adapted for a role in the host-parasite interaction in both plant- and animalparasitic nematodes. Similar adaptation of housekeeping proteins for roles in parasitism in animal and plant parasites has been described previously with peroxiredoxins, glutathione peroxidases and lipid binding proteins all known to be deployed by plant parasites and animal parasites in order to provide protection from host defences (reviewed by Jasmer et al., 2003). Convergent evolution between animal- and plant-parasitic nematodes is therefore a recurring theme in terms of how they cope with host derived stresses.

\section{Acknowledgements}

This work was supported by the EU 7th Framework REPHRAME project (KBBE.2010.1.4-09) and by FEDER Funds through the Operational Programme for Competitiveness Factors - COMPETE and National Funds through FCT - Foundation for Science and Technology under the Strategic Projects PEst-C/AGR/UI0115/ 2011 and PEst-OE/AGR/UI0115/2014. ME is funded by the FCT (Fundação para a Ciência e a Tecnologia, IP) under the $\mathrm{PhD}$ grant (SFRH/BD/84541/2012). The James Hutton Institute receives funding from the Scottish Government. The authors thank Dr P.J.A. Cock for advice on this MS.

\section{References}

Azeez, S., Babu, R.O., Aykkal, R. \& Narayanan, R. (2012). Virtual screening and in vitro assay of potential drug like inhibitors from spices against glutathione-S-transferase of filarial nematodes. Journal of Molecular Modeling 18, 151163.

Bellafiore, S., Shen, Z.X., Rosso, M.N., Abad, P., Shih, P. \& Briggs, S.P. (2008). Direct identification of the Meloidogyne incognita secretome reveals proteins with host cell reprogramming potential. PLoS Pathogens 4, e1000192.

Bendtsen, J.D., Nielsen, H., von Heijne, G. \& Brunak, S. (2004). Improved prediction of signal peptides: SignalP 3.0. Journal of Molecular Biology 340, 783-795.

Brophy, P.M. \& Barrett, J. (1990). Glutathione transferase in helminths. Parasitology 100, 345-349.

Brophy, P.M. \& Pritchard, D.I. (1994). Parasitic-helminth glutathione S-transferases: an update on their potential targets for immuno- and chemotherapy. Experimental Parasitology 79, 89-96.

Campbell, A.M., Teesdale-Spittle, P.H., Barrett, J., Liebau, E., Jefferies, J.A. \& Brophy, P.M. (2001). A common class of nematode glutathione S-transferase (GST) revealed by the theoretical proteome of the model organism Caenorhabditis elegans. Comparative Biochemistry and Physiology Part B 128, 701-708.

Cock, P.J.A., Chilton, J.M., Grüning, B., Johnson, J.E. \& Soranzo, N. (2015). NCBI BLAST+ integrated into Galaxy. GigaScience 4, 39.

Cotton, J.A., Lilley, C.J., Jones, L.M., Kikuchi, T., Reid, A.J., Thorpe, P., Tsai, I.J., Beasley, H., Blok, V., Cock, P.J.A. et al. (2014). The genome and life-stage specific transcriptomes of Globodera pallida elucidate key aspects of plant parasitism by a cyst nematode. Genome Biology 15, R43.

Cwiklinski, K., de la Torre-Escudero, E., Trelis, M., Bernal, D., Dufresne, P.J., Brennan, G.P., O’Neill, S., Tort, J., Paterson, S., Marcilla, A. et al. (2015). The extracellular vesicles of the helminth pathogen, Fasciola hepatica: biogenesis pathways and cargo molecules involved in parasite pathogenesis. Molecular and Cellular Proteomics 12, 3258-3273.

Dowling, D.J., Hamilton, C.M., Donnelly, S., La Course, J., Brophy, P.M., Dalton, J. \& O'Neill, S.M. (2010). Major secretory antigens of the helminth Fasciola hepatica activate a suppressive dendritic cell phenotype that attenuates Th17 cells but fails to activate $\mathrm{Th} 2$ immune responses. Infection and Immunity 78, 793-801.

Dubreuil, M., Magliano, E., Deleury, P., Abad, P. \& Rosso, M.N. (2007). Transcriptome analysis of root-knot nematode functions induced in the early stages of parasitism. New Phytologist 176, 426-436.

Espada, M., Silva, A.C., Eves-van den Akker, S., Cock, P.J.A., Mota, M. \& Jones, J.T. (2016). Identification and characterization of parasitism genes from the pinewood nematode Bur- 
saphelenchus xylophilus reveals a multi-layered detoxification strategy. Molecular Plant Pathology 17, 286-295.

Faria, J.M.S., Sena, I., Vieira da Silva, I., Ribeiro, B., Barbosa, P., Ascensão, L., Bennett, R.N., Mota, M. \& Figueiredo, A.C.F. (2015). In vitro co-cultures of Pinus pinaster with Bursaphelenchus xylophilus: a biotechnological approach to study pine wilt disease. Planta 241, 1325-1336.

Frova, C. (2006). Glutathione transferases in the genomics era: new insights and perspectives. Biomolecular Engineering 23, 149-169.

Fukuda, K. (1997). Physiological process of the symptom development and resistance mechanism in pine wilt disease. Journal of Forest Research 2, 171-181.

Gouy, M., Guindon, S. \& Gascuel, O. (2010). SeaView version 4: a multiplatform graphical user interface for sequence alignment and phylogenetic tree building. Molecular Biology and Evolution 27, 221-224.

Haegeman, A., Jacob, J., Vanholme, B., Kyndt, T., Mitreva, M. \& Gheysen, G. (2009). Expressed sequence tags of the peanut pod nematode Ditylenchus africanus: the first transcriptome analysis of an anguinid nematode. Molecular Biochemical Parasitology 167, 32-40.

Haegeman, A., Joseph, S. \& Gheysen, G. (2011). Analysis of the transcriptome of the root lesion nematode Pratylenchus coffeae generated by 454 sequencing technology. Molecular Biochemical Parasitology 178, 7-14.

Jacob, J., Mitreva, M., Vanholme, B. \& Gheysen, G. (2008). Exploring the transcriptome of the burrowing nematode Radopholus similis. Molecular Genetics and Genomics 280, 1-17.

Jasmer, D.P., Goverse, A. \& Smant, G. (2003). Parasitic nematode interactions with mammals and plants. Annual Review of Phytopathology 41, 245-270.

Jones, P., Binns, D., Chang, H., Fraser, M., Li, W., McAnulla, C., McWilliam, H., Maslen, J., Mitchell, A., Nuka, G. et al. (2014). InterProScan 5: genome-scale protein function classification. Bioinformatics 30, 1236-1240.
Kikuchi, T., Jones, J.T., Aikawa, T., Kosaka, H. \& Ogura, N. (2004). A family of glycosyl hydrolase family 45 cellulases from the pinewood nematode Bursaphelenchus xylophilus. FEBS Letters 572, 201-205.

Kikuchi, T., Cotton, J.A., Dalzell, J.J., Hasegawa, K., Kanzaki, N., McVeigh, P., Takanashi, T., Tsai, I.J., Assefa, S.A., Cock, P.J.A. et al. (2011). Genomic insights into the origin of parasitism in the emerging plant pathogen Bursaphelenchus xylophilus. PLoS Pathogens 7, e1002219.

Kuroda, K. (1991). Mechanism of cavitation development in the pine wilt disease. European Journal of Forest Pathology 21, 82-89.

Kuroda, K., Yamada, T. \& Ito, S. (1991). Bursaphelenchus xylophilus induced pine wilt: factors associated with resistance. European Journal of Forest Pathology 21, 430-438.

LaCourse, E.J., Perally, S., Morphew, R.M., Moxon, J.V., Prescott, M., Dowling, D.J., O’Neill, S.M., Kipar, A., Hetzel, U., Hoey, E. et al. (2012). The sigma class glutathione transferase from the liver fluke Fasciola hepatica. PLoS Neglected Tropical Diseases 6, e1666.

Matoušková, P., Vokřál, I., Lamka, J. \& Skálová, L. (2016). The role of xenobiotic-metabolizing enzymes in anthelmintic deactivation and resistance in helminths. Trends in Parasitology, in press. DOI:10.1016/j.pt.2016.02.004.

Precious, W.Y. \& Barrett, J. (1989). Xenobiotic metabolism in helminths. Parasitology Today 5, 156-160.

Shinya, R., Morisaka, H., Kikuchi, T., Takeuchi, Y., Ueda, M. \& Futai, K. (2013). Secretome analysis of the pine wood nematode Bursaphelenchus xylophilus reveals the tangled roots of parasitism and its potential for molecular mimicry. PLoS ONE 8, e67377.

Torres-Rivera, A. \& Landa, A. (2008). Gluthathione transferases from parasites: a biochemical view. Acta Tropica 105, 99112.

van Rossum, A.J., Jefferies, J.R., Rijsewijk, F.A.M., LaCourse, E.J., Teesdale-Spittle, P., Barrett, J., Tait, A. \& Brophy, P.M. (2004). Binding of hematin by a new class of glutathione transferase from the blood-feeding parasitic nematode Haemonchus contortus. Infection and Immunity 72, 2780-2790. 


\section{Supplementary material}

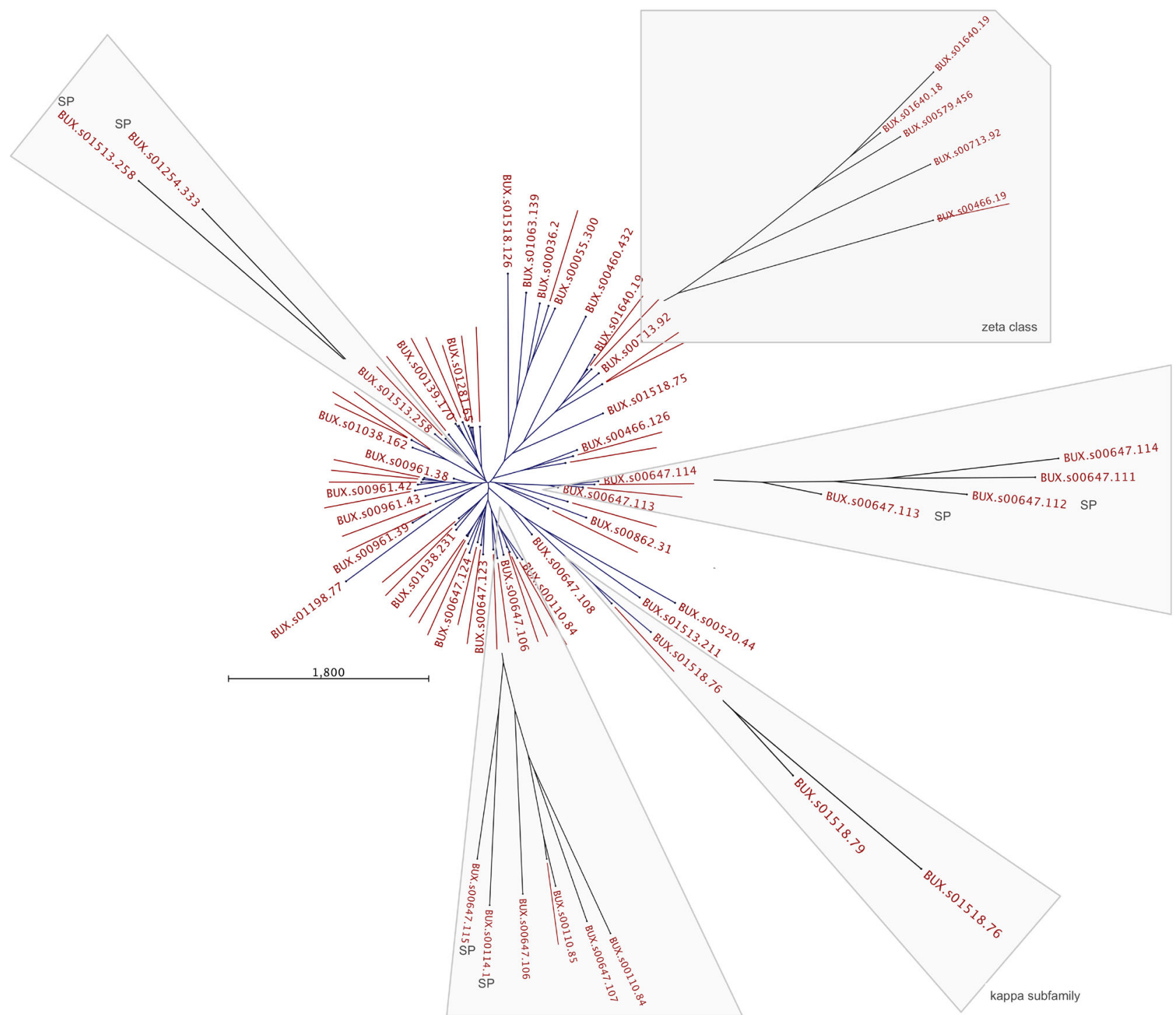

Fig. S1. Neighbour-joining phylogenetic tree of all 70 protein sequences from Bursaphelenchus xylophilus. The highlighted clusters in grey boxes represent the kappa subfamily, the zeta class and the clusters with the protein of interest (BUX.s00647.112) and the proteins with predicted signal peptide. This tree confirms that the clusters are not an artefact of the maximum-likelihood phylogenetic tree. This figure is published in colour in the online edition of this journal, which can be accessed via http://booksandjournals.brillonline.com/ content/journals/15685411. 
Table S1. Protein domains predicted for all 70 putative GSTs from Bursaphelenchus xylophilus. Each domain is represented by the InterProScan identification code and for some of the proteins the family was identified.

\begin{tabular}{|c|c|c|c|c|}
\hline Gene code* & Protein family & Number domain 1 & Number domain 2 & Number domain 3 \\
\hline BUX.c04223.1 & None & $\begin{array}{l}\text { IPR010987 Glutathione } \\
\text { S-transferase, } \\
\text { C-terminal-like }\end{array}$ & $\begin{array}{l}\text { IPR004046 Glutathione } \\
\text { S-transferase, C-terminal }\end{array}$ & \\
\hline BUX.c09083.1 & None & $\begin{array}{l}\text { IPR012336 Thioredoxin-like } \\
\text { fold }\end{array}$ & $\begin{array}{l}\text { IPR004045 Glutathione } \\
\text { S-transferase, N-terminal }\end{array}$ & $\begin{array}{l}\text { IPR010987 Glutathione } \\
\text { S-transferase, C-terminal-like }\end{array}$ \\
\hline BUX.s00110.84 & None & $\begin{array}{l}\text { IPR012336 Thioredoxin-like } \\
\text { fold }\end{array}$ & $\begin{array}{l}\text { IPR004045 Glutathione } \\
\text { S-transferase, N-terminal }\end{array}$ & $\begin{array}{l}\text { IPR010987 Glutathione } \\
\text { S-transferase, C-terminal-like }\end{array}$ \\
\hline BUX.s00110.85 & None & $\begin{array}{l}\text { IPR012336 Thioredoxin-like } \\
\text { fold }\end{array}$ & $\begin{array}{l}\text { IPR004045 Glutathione } \\
\text { S-transferase, N-terminal }\end{array}$ & $\begin{array}{l}\text { IPR010987 Glutathione } \\
\text { S-transferase, C-terminal-like }\end{array}$ \\
\hline BUX.s00114.1 & None & $\begin{array}{l}\text { IPR012336 Thioredoxin-like } \\
\text { fold }\end{array}$ & $\begin{array}{l}\text { IPR004045 Glutathione } \\
\text { S-transferase, N-terminal }\end{array}$ & $\begin{array}{l}\text { IPR010987 Glutathione } \\
\text { S-transferase, C-terminal-like }\end{array}$ \\
\hline BUX.s00116.427 & $\begin{array}{l}\text { Failed axon } \\
\text { connections } \\
\text { IPR026928 }\end{array}$ & $\begin{array}{l}\text { IPR012336 Thioredoxin-like } \\
\text { fold }\end{array}$ & $\begin{array}{l}\text { IPR010987 Glutathione } \\
\text { S-transferase, } \\
\text { C-terminal-like }\end{array}$ & $\begin{array}{l}\text { IPR004046 Glutathione } \\
\text { S-transferase, C-terminal }\end{array}$ \\
\hline BUX.s00116.457 & None & $\begin{array}{l}\text { IPR012336 Thioredoxin-like } \\
\text { fold }\end{array}$ & $\begin{array}{l}\text { IPR004045 Glutathione } \\
\text { S-transferase, N-terminal }\end{array}$ & $\begin{array}{l}\text { IPR010987 Glutathione } \\
\text { S-transferase, C-terminal-like }\end{array}$ \\
\hline BUX.s00116.338 & None & $\begin{array}{l}\text { IPR012336 Thioredoxin-like } \\
\text { fold }\end{array}$ & $\begin{array}{l}\text { IPR004045 Glutathione } \\
\text { S-transferase, N-terminal }\end{array}$ & $\begin{array}{l}\text { IPR010987 Glutathione } \\
\text { S-transferase, C-terminal-like }\end{array}$ \\
\hline BUX.s00139.169 & None & $\begin{array}{l}\text { IPR012336 Thioredoxin-like } \\
\text { fold }\end{array}$ & $\begin{array}{l}\text { IPR004045 Glutathione } \\
\text { S-transferase, N-terminal }\end{array}$ & $\begin{array}{l}\text { IPR010987 Glutathione } \\
\text { S-transferase, C-terminal-like }\end{array}$ \\
\hline BUX.s00139.170 & None & $\begin{array}{l}\text { IPR012336 Thioredoxin-like } \\
\text { fold }\end{array}$ & $\begin{array}{l}\text { IPR004045 Glutathione } \\
\text { S-transferase, N-terminal }\end{array}$ & $\begin{array}{l}\text { IPR010987 Glutathione } \\
\text { S-transferase, C-terminal-like }\end{array}$ \\
\hline BUX.s00460.83 & None & $\begin{array}{l}\text { IPR012336 Thioredoxin-like } \\
\text { fold }\end{array}$ & $\begin{array}{l}\text { IPR004045 Glutathione } \\
\text { S-transferase, N-terminal }\end{array}$ & $\begin{array}{l}\text { IPR010987 Glutathione } \\
\text { S-transferase, C-terminal-like }\end{array}$ \\
\hline BUX.s00466.126 & None & $\begin{array}{l}\text { IPR012336 Thioredoxin-like } \\
\text { fold }\end{array}$ & $\begin{array}{l}\text { IPR004045 Glutathione } \\
\text { S-transferase, N-terminal }\end{array}$ & $\begin{array}{l}\text { IPR010987 Glutathione } \\
\text { S-transferase, C-terminal-like }\end{array}$ \\
\hline BUX.s00466.66 & None & $\begin{array}{l}\text { IPR012336 Thioredoxin-like } \\
\text { fold }\end{array}$ & $\begin{array}{l}\text { IPR004045 Glutathione } \\
\text { S-transferase, N-terminal }\end{array}$ & $\begin{array}{l}\text { IPR010987 Glutathione } \\
\text { S-transferase, C-terminal-like }\end{array}$ \\
\hline BUX.s00631.40 & None & $\begin{array}{l}\text { IPR012336 Thioredoxin-like } \\
\text { fold }\end{array}$ & $\begin{array}{l}\text { IPR004045 Glutathione } \\
\text { S-transferase, N-terminal }\end{array}$ & $\begin{array}{l}\text { IPR010987 Glutathione } \\
\text { S-transferase, C-terminal-like }\end{array}$ \\
\hline BUX.s00647.107 & None & $\begin{array}{l}\text { IPR012336 Thioredoxin-like } \\
\text { fold }\end{array}$ & $\begin{array}{l}\text { IPR004045 Glutathione } \\
\text { S-transferase, N-terminal }\end{array}$ & $\begin{array}{l}\text { IPR010987 Glutathione } \\
\text { S-transferase, C-terminal-like }\end{array}$ \\
\hline BUX.s00647.123 & None & $\begin{array}{l}\text { IPR012336 Thioredoxin-like } \\
\text { fold }\end{array}$ & $\begin{array}{l}\text { IPR004045 Glutathione } \\
\text { S-transferase, N-terminal }\end{array}$ & \\
\hline BUX.s00647.116 & None & $\begin{array}{l}\text { IPR012336 Thioredoxin-like } \\
\text { fold }\end{array}$ & $\begin{array}{l}\text { IPR004045 Glutathione } \\
\text { S-transferase, N-terminal }\end{array}$ & \\
\hline BUX.s00647.121 & None & $\begin{array}{l}\text { IPR012336 Thioredoxin-like } \\
\text { fold }\end{array}$ & $\begin{array}{l}\text { IPR004045 Glutathione } \\
\text { S-transferase, N-terminal }\end{array}$ & $\begin{array}{l}\text { IPR010987 Glutathione } \\
\text { S-transferase, C-terminal-like }\end{array}$ \\
\hline BUX.s00647.112 & None & $\begin{array}{l}\text { IPR012336 Thioredoxin-like } \\
\text { fold }\end{array}$ & $\begin{array}{l}\text { IPR004045 Glutathione } \\
\text { S-transferase, N-terminal }\end{array}$ & $\begin{array}{l}\text { IPR010987 Glutathione } \\
\text { S-transferase, C-terminal-like }\end{array}$ \\
\hline BUX.s00647.118 & None & $\begin{array}{l}\text { IPR012336 Thioredoxin-like } \\
\text { fold }\end{array}$ & $\begin{array}{l}\text { IPR004045 Glutathione } \\
\text { S-transferase, N-terminal }\end{array}$ & $\begin{array}{l}\text { IPR010987 Glutathione } \\
\text { S-transferase, C-terminal-like }\end{array}$ \\
\hline BUX.s00647.119 & None & $\begin{array}{l}\text { IPR012336 Thioredoxin-like } \\
\text { fold }\end{array}$ & $\begin{array}{l}\text { IPR004045 Glutathione } \\
\text { S-transferase, N-terminal }\end{array}$ & $\begin{array}{l}\text { IPR010987 Glutathione } \\
\text { S-transferase, C-terminal-like }\end{array}$ \\
\hline BUX.s00647.113 & None & $\begin{array}{l}\text { IPR012336 Thioredoxin-like } \\
\text { fold }\end{array}$ & $\begin{array}{l}\text { IPR004045 Glutathione } \\
\text { S-transferase, N-terminal }\end{array}$ & \\
\hline BUX.s00647.126 & None & $\begin{array}{l}\text { IPR012336 Thioredoxin-like } \\
\text { fold }\end{array}$ & $\begin{array}{l}\text { IPR004045 Glutathione } \\
\text { S-transferase, N-terminal }\end{array}$ & $\begin{array}{l}\text { IPR010987 Glutathione } \\
\text { S-transferase, C-terminal-like }\end{array}$ \\
\hline
\end{tabular}


Table S1. (Continued.)

\begin{tabular}{|c|c|c|c|c|}
\hline Gene code* & Protein family & Number domain 1 & Number domain 2 & Number domain 3 \\
\hline BUX.s00647.124 & None & $\begin{array}{l}\text { IPR012336 Thioredoxin-like } \\
\text { fold }\end{array}$ & $\begin{array}{l}\text { IPR004045 Glutathione } \\
\text { S-transferase, N-terminal }\end{array}$ & $\begin{array}{l}\text { IPR010987 Glutathione } \\
\text { S-transferase, C-terminal-like }\end{array}$ \\
\hline BUX.s00647.108 & None & $\begin{array}{l}\text { IPR012336 Thioredoxin-like } \\
\text { fold }\end{array}$ & $\begin{array}{l}\text { IPR004045 Glutathione } \\
\text { S-transferase, N-terminal }\end{array}$ & \\
\hline BUX.s00647.115 & None & $\begin{array}{l}\text { IPR012336 Thioredoxin-like } \\
\text { fold }\end{array}$ & $\begin{array}{l}\text { IPR004045 Glutathione } \\
\text { S-transferase, N-terminal }\end{array}$ & \\
\hline BUX.s00647.111 & None & $\begin{array}{l}\text { IPR012336 Thioredoxin-like } \\
\text { fold }\end{array}$ & $\begin{array}{l}\text { IPR004045 Glutathione } \\
\text { S-transferase, N-terminal }\end{array}$ & $\begin{array}{l}\text { IPR010987 Glutathione } \\
\text { S-transferase, C-terminal-like }\end{array}$ \\
\hline BUX.s00647.110 & None & $\begin{array}{l}\text { IPR012336 Thioredoxin-like } \\
\text { fold }\end{array}$ & $\begin{array}{l}\text { IPR004045 Glutathione } \\
\text { S-transferase, N-terminal }\end{array}$ & $\begin{array}{l}\text { IPR010987 Glutathione } \\
\text { S-transferase, C-terminal-like }\end{array}$ \\
\hline BUX.s00647.125 & None & $\begin{array}{l}\text { IPR012336 Thioredoxin-like } \\
\text { fold }\end{array}$ & $\begin{array}{l}\text { IPR004045 Glutathione } \\
\text { S-transferase, N-terminal }\end{array}$ & $\begin{array}{l}\text { IPR010987 Glutathione } \\
\text { S-transferase, C-terminal-like }\end{array}$ \\
\hline BUX.s00647.122 & None & $\begin{array}{l}\text { IPR012336 Thioredoxin-like } \\
\text { fold }\end{array}$ & $\begin{array}{l}\text { IPR004045 Glutathione } \\
\text { S-transferase, N-terminal }\end{array}$ & $\begin{array}{l}\text { IPR010987 Glutathione } \\
\text { S-transferase, C-terminal-like }\end{array}$ \\
\hline BUX.s00862.31 & None & $\begin{array}{l}\text { IPR012336 Thioredoxin-like } \\
\text { fold }\end{array}$ & $\begin{array}{l}\text { IPR004045 Glutathione } \\
\text { S-transferase, N-terminal }\end{array}$ & \\
\hline BUX.s00961.40 & None & $\begin{array}{l}\text { IPR012336 Thioredoxin-like } \\
\text { fold }\end{array}$ & $\begin{array}{l}\text { IPR004045 Glutathione } \\
\text { S-transferase, N-terminal }\end{array}$ & $\begin{array}{l}\text { IPR010987 Glutathione } \\
\text { S-transferase, C-terminal-like }\end{array}$ \\
\hline BUX.s00961.38 & None & $\begin{array}{l}\text { IPR012336 Thioredoxin-like } \\
\text { fold }\end{array}$ & $\begin{array}{l}\text { IPR004045 Glutathione } \\
\text { S-transferase, N-terminal }\end{array}$ & \\
\hline BUX.s00961.36 & None & $\begin{array}{l}\text { IPR012336 Thioredoxin-like } \\
\text { fold }\end{array}$ & $\begin{array}{l}\text { IPR004045 Glutathione } \\
\text { S-transferase, N-terminal }\end{array}$ & $\begin{array}{l}\text { IPR010987 Glutathione } \\
\text { S-transferase, C-terminal-like }\end{array}$ \\
\hline BUX.s00961.42 & None & $\begin{array}{l}\text { IPR012336 Thioredoxin-like } \\
\text { fold }\end{array}$ & $\begin{array}{l}\text { IPR004045 Glutathione } \\
\text { S-transferase, N-terminal }\end{array}$ & $\begin{array}{l}\text { IPR010987 Glutathione } \\
\text { S-transferase, C-terminal-like }\end{array}$ \\
\hline BUX.s00961.37 & None & $\begin{array}{l}\text { IPR012336 Thioredoxin-like } \\
\text { fold }\end{array}$ & $\begin{array}{l}\text { IPR004045 Glutathione } \\
\text { S-transferase, N-terminal }\end{array}$ & $\begin{array}{l}\text { IPR010987 Glutathione } \\
\text { S-transferase, C-terminal-like }\end{array}$ \\
\hline BUX.s00961.43 & None & $\begin{array}{l}\text { IPR012336 Thioredoxin-like } \\
\text { fold }\end{array}$ & $\begin{array}{l}\text { IPR004045 Glutathione } \\
\text { S-transferase, N-terminal }\end{array}$ & $\begin{array}{l}\text { IPR010987 Glutathione } \\
\text { S-transferase, C-terminal-like }\end{array}$ \\
\hline BUX.s00961.41 & None & $\begin{array}{l}\text { IPR012336 Thioredoxin-like } \\
\text { fold }\end{array}$ & $\begin{array}{l}\text { IPR004045 Glutathione } \\
\text { S-transferase, N-terminal }\end{array}$ & $\begin{array}{l}\text { IPR010987 Glutathione } \\
\text { S-transferase, C-terminal-like }\end{array}$ \\
\hline BUX.s00983.23 & None & $\begin{array}{l}\text { IPR012336 Thioredoxin-like } \\
\text { fold }\end{array}$ & $\begin{array}{l}\text { IPR004045 Glutathione } \\
\text { S-transferase, N-terminal }\end{array}$ & $\begin{array}{l}\text { IPR010987 Glutathione } \\
\text { S-transferase, C-terminal-like }\end{array}$ \\
\hline BUX.s01038.67 & None & $\begin{array}{l}\text { IPR012336 Thioredoxin-like } \\
\text { fold }\end{array}$ & $\begin{array}{l}\text { IPR004045 Glutathione } \\
\text { S-transferase, N-terminal }\end{array}$ & \\
\hline BUX.s01038.162 & None & $\begin{array}{l}\text { IPR012336 Thioredoxin-like } \\
\text { fold }\end{array}$ & $\begin{array}{l}\text { IPR004045 Glutathione } \\
\text { S-transferase, N-terminal }\end{array}$ & $\begin{array}{l}\text { IPR010987 Glutathione } \\
\text { S-transferase, C-terminal-like }\end{array}$ \\
\hline BUX.s01038.66 & None & $\begin{array}{l}\text { IPR010987 Glutathione } \\
\text { S-transferase, } \\
\text { C-terminal-like }\end{array}$ & $\begin{array}{l}\text { IPR004046 Glutathione } \\
\text { S-transferase, C-terminal }\end{array}$ & \\
\hline BUX.s01038.231 & None & $\begin{array}{l}\text { IPR012336 Thioredoxin-like } \\
\text { fold }\end{array}$ & $\begin{array}{l}\text { IPR004045 Glutathione } \\
\text { S-transferase, N-terminal }\end{array}$ & $\begin{array}{l}\text { IPR010987 Glutathione } \\
\text { S-transferase, C-terminal-like }\end{array}$ \\
\hline BUX.s01092.134 & None & $\begin{array}{l}\text { IPR012336 Thioredoxin-like } \\
\text { fold }\end{array}$ & $\begin{array}{l}\text { IPR004045 Glutathione } \\
\text { S-transferase, N-terminal }\end{array}$ & $\begin{array}{l}\text { IPR010987 Glutathione } \\
\text { S-transferase, C-terminal-like }\end{array}$ \\
\hline BUX.s01254.333 & None & $\begin{array}{l}\text { IPR012336 Thioredoxin-like } \\
\text { fold }\end{array}$ & $\begin{array}{l}\text { IPR004045 Glutathione } \\
\text { S-transferase, N-terminal }\end{array}$ & $\begin{array}{l}\text { IPR010987 Glutathione } \\
\text { S-transferase, C-terminal-like }\end{array}$ \\
\hline BUX.s01254.332 & None & $\begin{array}{l}\text { IPR012336 Thioredoxin-like } \\
\text { fold }\end{array}$ & $\begin{array}{l}\text { IPR004045 Glutathione } \\
\text { S-transferase, N-terminal }\end{array}$ & $\begin{array}{l}\text { IPR010987 Glutathione } \\
\text { S-transferase, C-terminal-like }\end{array}$ \\
\hline BUX.s01281.65 & None & $\begin{array}{l}\text { IPR012336 Thioredoxin-like } \\
\text { fold }\end{array}$ & $\begin{array}{l}\text { IPR004045 Glutathione } \\
\text { S-transferase, N-terminal }\end{array}$ & $\begin{array}{l}\text { IPR010987 Glutathione } \\
\text { S-transferase, C-terminal-like }\end{array}$ \\
\hline
\end{tabular}


Table S1. (Continued.)

\begin{tabular}{|c|c|c|c|c|}
\hline Gene code* & Protein family & Number domain 1 & Number domain 2 & Number domain 3 \\
\hline BUX.s01281.64 & None & $\begin{array}{l}\text { IPR012336 Thioredoxin-like } \\
\text { fold }\end{array}$ & $\begin{array}{l}\text { IPR004045 Glutathione } \\
\text { S-transferase, N-terminal }\end{array}$ & $\begin{array}{l}\text { IPR010987 Glutathione } \\
\text { S-transferase, C-terminal-like }\end{array}$ \\
\hline BUX.s01368.1 & None & $\begin{array}{l}\text { IPR012336 Thioredoxin-like } \\
\text { fold }\end{array}$ & $\begin{array}{l}\text { IPR004045 Glutathione } \\
\text { S-transferase, N-terminal }\end{array}$ & $\begin{array}{l}\text { IPR010987 Glutathione } \\
\text { S-transferase, C-terminal-like }\end{array}$ \\
\hline BUX.s01513.258 & None & $\begin{array}{l}\text { IPR012336 Thioredoxin-like } \\
\text { fold }\end{array}$ & $\begin{array}{l}\text { IPR004045 Glutathione } \\
\text { S-transferase, N-terminal }\end{array}$ & $\begin{array}{l}\text { IPR010987 Glutathione } \\
\text { S-transferase, C-terminal-like }\end{array}$ \\
\hline BUX.s01518.75 & None & $\begin{array}{l}\text { IPR012336 Thioredoxin-like } \\
\text { fold }\end{array}$ & $\begin{array}{l}\text { IPR010987 Glutathione } \\
\text { S-transferase, } \\
\text { C-terminal-like }\end{array}$ & $\begin{array}{l}\text { IPR004046 Glutathione } \\
\text { S-transferase, C-terminal }\end{array}$ \\
\hline BUX.s00520.44 & None & $\begin{array}{l}\text { IPR012336 Thioredoxin-like } \\
\text { fold }\end{array}$ & $\begin{array}{l}\text { IPR001853 DSBA-like } \\
\text { thioredoxin domain }\end{array}$ & \\
\hline BUX.s00647.114 & None & $\begin{array}{l}\text { IPR010987 Glutathione } \\
\text { S-transferase, } \\
\text { C-terminal-like }\end{array}$ & & \\
\hline BUX.s01513.211 & None & $\begin{array}{l}\text { IPR012336 Thioredoxin-like } \\
\text { fold }\end{array}$ & $\begin{array}{l}\text { IPR001853 DSBA-like } \\
\text { thioredoxin domain }\end{array}$ & \\
\hline BUX.s01518.79 & None & $\begin{array}{l}\text { IPR001853 DSBA-like } \\
\text { thioredoxin domain }\end{array}$ & $\begin{array}{l}\text { IPR012336 } \\
\text { Thioredoxin-like fold }\end{array}$ & \\
\hline BUX.s01518.76 & $\begin{array}{l}\text { HCCA isomerase/ } \\
\text { glutathione } \\
\text { S-transferase } \\
\text { kappa } \\
\text { (IPR014440) }\end{array}$ & $\begin{array}{l}\text { IPR012336 Thioredoxin-like } \\
\text { fold }\end{array}$ & $\begin{array}{l}\text { IPR001853 DSBA-like } \\
\text { thioredoxin domain }\end{array}$ & \\
\hline BUX.s00036.2 & None & $\begin{array}{l}\text { IPR010987 Glutathione } \\
\text { S-transferase, } \\
\text { C-terminal-like }\end{array}$ & $\begin{array}{l}\text { IPR004046 Glutathione } \\
\text { S-transferase, C-terminal }\end{array}$ & \\
\hline BUX.s00055.300 & None & $\begin{array}{l}\text { IPR012336 Thioredoxin-like } \\
\text { fold }\end{array}$ & $\begin{array}{l}\text { IPR010987 Glutathione } \\
\text { S-transferase, } \\
\text { C-terminal-like }\end{array}$ & $\begin{array}{l}\text { IPR004046 Glutathione } \\
\text { S-transferase, C-terminal }\end{array}$ \\
\hline BUX.s00460.432 & None & IPR2109 Glutaredoxin & $\begin{array}{l}\text { IPR012336 } \\
\text { Thioredoxin-like fold }\end{array}$ & $\begin{array}{l}\text { IPR004045 Glutathione } \\
\text { S-transferase, N-terminal }\end{array}$ \\
\hline BUX.s00466.18 & $\begin{array}{l}\text { Maleylacetoacetate } \\
\text { isomerase } \\
\text { (IPR005955) }\end{array}$ & $\begin{array}{l}\text { IPR005955 } \\
\text { Maleyacetoacetate isomerase }\end{array}$ & $\begin{array}{l}\text { IPR012336 } \\
\text { Thioredoxin-like fold }\end{array}$ & $\begin{array}{l}\text { IPR004045 Glutathione } \\
\text { S-transferase, N-terminal }\end{array}$ \\
\hline BUX.s00466.19 & $\begin{array}{l}\text { Maleylacetoacetate } \\
\text { isomerase } \\
\text { (IPR005955) }\end{array}$ & $\begin{array}{l}\text { IPR005955 } \\
\text { Maleyacetoacetate isomerase }\end{array}$ & $\begin{array}{l}\text { IPR012336 } \\
\text { Thioredoxin-like fold }\end{array}$ & $\begin{array}{l}\text { IPR004045 Glutathione } \\
\text { S-transferase, N-terminal }\end{array}$ \\
\hline BUX.s00579.456 & $\begin{array}{l}\text { Maleylacetoacetate } \\
\text { isomerase } \\
\text { (IPR005955) }\end{array}$ & $\begin{array}{l}\text { IPR005955 } \\
\text { Maleyacetoacetate isomerase }\end{array}$ & $\begin{array}{l}\text { IPR } 012336 \\
\text { Thioredoxin-like fold }\end{array}$ & $\begin{array}{l}\text { IPR004045 Glutathione } \\
\text { S-transferase, N-terminal }\end{array}$ \\
\hline Bux.s00647.106 & None & $\begin{array}{l}\text { IPR012336 Thioredoxin-like } \\
\text { fold }\end{array}$ & $\begin{array}{l}\text { IPR010987 Glutathione } \\
\text { S-transferase, } \\
\text { C-terminal-like }\end{array}$ & \\
\hline BUX.s00713.92 & $\begin{array}{l}\text { Maleylacetoacetate } \\
\text { isomerase } \\
\text { (IPR005955) }\end{array}$ & $\begin{array}{l}\text { IPR005955 } \\
\text { Maleyacetoacetate isomerase }\end{array}$ & $\begin{array}{l}\text { IPR012336 } \\
\text { Thioredoxin-like fold }\end{array}$ & $\begin{array}{l}\text { IPR004045 Glutathione } \\
\text { S-transferase, N-terminal }\end{array}$ \\
\hline
\end{tabular}


Table S1. (Continued.)

\begin{tabular}{|c|c|c|c|c|}
\hline Gene code* & Protein family & Number domain 1 & Number domain 2 & Number domain 3 \\
\hline BUX.s00961.39 & None & $\begin{array}{l}\text { IPR010987 Glutathione } \\
\text { S-transferase, } \\
\text { C-terminal-like }\end{array}$ & & \\
\hline BUX.s01063.139 & None & $\begin{array}{l}\text { IPR010987 Glutathione } \\
\text { S-transferase, } \\
\text { C-terminal-like }\end{array}$ & $\begin{array}{l}\text { IPR004046 Glutathione } \\
\text { S-transferase, C-terminal }\end{array}$ & \\
\hline BUX.s01198.77 & None & $\begin{array}{l}\text { IPR012336 Thioredoxin-like } \\
\text { fold }\end{array}$ & $\begin{array}{l}\text { IPR010987 Glutathione } \\
\text { S-transferase, } \\
\text { C-terminal-like }\end{array}$ & \\
\hline BUX.s01518.126 & None & $\begin{array}{l}\text { IPR012336 Thioredoxin-like } \\
\text { fold }\end{array}$ & $\begin{array}{l}\text { IPR010987 Glutathione } \\
\text { S-transferase, } \\
\text { C-terminal-like }\end{array}$ & $\begin{array}{l}\text { IPR004046 Glutathione } \\
\text { S-transferase, C-terminal }\end{array}$ \\
\hline BUX.s01640.19 & None & $\begin{array}{l}\text { IPR012336 Thioredoxin-like } \\
\text { fold }\end{array}$ & $\begin{array}{l}\text { IPR004045 Glutathione } \\
\text { S-transferase, N-terminal }\end{array}$ & $\begin{array}{l}\text { IPR010987 Glutathione } \\
\text { S-transferase, C-terminal-like }\end{array}$ \\
\hline BUX.s01640.18 & $\begin{array}{l}\text { Maleylacetoacetate } \\
\text { isomerase } \\
\text { (IPR005955) }\end{array}$ & $\begin{array}{l}\text { IPR012336 Thioredoxin-like } \\
\text { fold }\end{array}$ & $\begin{array}{l}\text { IPR004045 Glutathione } \\
\text { S-transferase, N-terminal }\end{array}$ & $\begin{array}{l}\text { IPR010987 Glutathione } \\
\text { S-transferase, C-terminal-like }\end{array}$ \\
\hline
\end{tabular}

\footnotetext{
* According to PWN gene calls of the genome (version 1.2); available in GeneDB (www.genedb.org/Homepage/Bxylophilus).
} 